\title{
EXPLORATION OF SOIL MICROBIAL DIVERSITY IN RHIZOSPHERE OF SOME TRITICEAE SPECIES IN SHANXI, CHINA
}

\author{
YANG, Z. P. $.^{1{ }^{* *}}-$ YANG, W. ${ }^{2 \#}-$ HAO, J. ${ }^{3}-$ SUN, M. ${ }^{1}-$ GAO, Z. Q. - KHAN, S. ${ }^{1}-$ ANWAR, S. ${ }^{4}-$ \\ DU, T. ${ }^{1}-$ XUE, N. ${ }^{1}$ \\ ${ }^{I}$ College of Agriculture, Shanxi Agricultural University, Taigu 030801, Shanxi, P. R. China \\ ${ }^{2}$ College of Life Science, North China University of Science and Technology \\ Tangshan, P. R. China \\ ${ }^{3}$ College of Food Science and Engineering, Shanxi Agricultural University \\ Taigu 030801, Shanxi, P. R. China \\ ${ }^{4}$ College of Plant Science and Technology, Huazhong Agricultural University, Wuhan, \\ P. R. China \\ ${ }^{\#}$ These authors equally contributed to the study. \\ *Corresponding author \\ e-mail: yangzp.2@163.com \\ (Received $16^{\text {th }}$ Jun 2018; accepted 22 ${ }^{\text {nd }}$ Aug 2018)
}

\begin{abstract}
Microbial diversity in rhizospheric soil plays a vital role for sustainable crop production and maintenance of soil quality. The aim of this study was to evaluate microbial diversity in rhizosphere of Triticeae species by denaturing gradient gel electrophoresis (DGGE) and DNA sequencing technique and to select suitable varieties being introduced to Shanxi province to improve soil quality and crop production. In the experiment, there were nine introduced varieties of Triticeae crops and one local breeding winter wheat variety (S1, Shannong 129, white grain, middle-gluten). The nine Triticeae varieties included six common wheat varieties, one durum wheat variety (S8, Yavaros F9), one rye variety (S9, rye 4R) and one triticale variety (S10, taisi 1). The six common wheat varieties were: Yannong 19 (S2, white grain, middle-gluten, winter), Huaimai 18 (S3, white, middle-gluten, half-winter), Yumai 34 (S4, white, high-gluten, spring), Shannong zixiaomai (S5, purple, middle-gluten, winter), Heixiaomai 031244 (S6, black, high-gluten, winter), Wumai 202W22 (S7, black, high-gluten, spring). Results showed that the rhizospheric bacterial and fungal community varied with Triticeae genera and wheat varieties. Huaimai 18 stimulated the increase of uncultured bacterium and Nabis ferus, while Shannong 129 stimulated the increase of uncultured Chloroflexi bacterium. Bacterial diversity was higher in rhizosphere of Heixiaomai 031244, whereas, fungal diversity was relatively higher in Huaimai 18 . Hence, our study implies that, Huaimai 18, Yannong 19, and Heixiaomai 031244 could be planted in Shanxi province to develop high quality wheat variety resources and rye $4 \mathrm{R}$ as a feed crop for planting structure adjustment.
\end{abstract}

Keywords: bacterial community, rhizobial fungal, common wheat, rye, triticale, durum wheat, DGGE

\section{Introduction}

Soil microbes are an important component of soil fertility and play critical roles in ecosystems and influence many important ecosystem processes such as organic matter mineralization, humus formation and decomposition, carbon-nitrogen cycling, soil formation, plant nutrient acquisition and so on ( $\mathrm{Li}, 1993)$, although they are very small parts of the soil composition (Jia et al., 2004b). Especially in terrestrial ecosystems, soil microbes make important contributions to plant productivity and diversity. Van der Heijden et al. (2008) showed that mycorrhizal fungi and nitrogen-fixing bacteria were 
responsible for about 5-20\% (in grassland and savannah) to $80 \%$ (in temperate and boreal forests) of all nitrogen, and up to $75 \%$ of phosphorus, that was annually acquired by the vegetation.

Crop roots spread widely in farmland soil, forming special soil microbial habitat and affecting soil fertility and nutrient circulation (Jia et al., 2004a). Guriguis et al. (1969) had divided farmland soil into rhizosphere and non-rhizosphere soil. The bioactivity of rhizosphere soil was significantly higher than that of non-rhizosphere soil during crop growth period (Takuya, 1990). Organic matter of rhizosphere soil came from crop roots, which could account for about 30\% of plant photosynthetic products (Martin, 1977). The amount of rhizosphere soil microbial carbon accounted for about 3 percent of the total soil organic carbon (Joergensen, 2000). The ratio of rhizosphere and nonrhizosphere soil microbial biomass $(\mathrm{R} / \mathrm{S})$ was in turn bacterial $>$ fungus $>$ actinomycetes (Lou, 1962; Chen, 1990). Rhizospheric microbes can stabilize soil structure, accumulate organic residue, fix nitrogen, and remove toxin (Doran and Zeiss, 2000; Gomes et al., 2003; Sainia et al., 2004; Wakelin et al., 2008). Also, rhizospheric microbial species and their populations can considerably maintain crops healthy and improve crop growth (Acosta-Martínez et al., 2010; Aira et al., 2010). There were a few relevant reports about the effects of these factors, such as soil type and properties, soil nutrition, cropping system, cultivating management practice, varietal differences within a species, plant age, plant species, and plant genotype (Mar et al., 2000; Xu et al., 2009; Buyer et al., 2010; Teaumroong et al., 2010; Piromyou et al., 2011) on rhizospheric soil microbial diversity as one of the most sensitive biological indicators for monitoring soil quality changes (Brock, 1987; Niemi et al., 2001). However, very few reports were published about rhizospheric soils' microbial diversities when a number of wheat resources were introduced into a particular area.

Wheat (Triticum aestivum L.) is one of the most important crops due to having the biggest cultivated area and yield as well as having the widest geographical distribution in the world (FAOSTAT, 2017). In China, the planting area and yield of wheat is next to that of rice. Shanxi Province, located at the eastern edge of loess plateau, is one of the main provinces of wheat production in China. According to wheat ecological quality regionalization, Shanxi province belongs to strong-gluten and middle-gluten wheat producing area in China (He et al., 2006).

Grain quality is determined by the environment and interaction between environment and genotype (Kaya and Akcura, 2014). Grain quality of wheat is characterized by a number of physical and compositional properties and threshold requirements are set according to end-use requirements. For instance in wheat whole-grain physical properties such as size and shape, grain protein content and protein composition is also an important quality measure which defines nutritional and end-use properties of dough mixing, dough strength and effect the efficiency of the bread making process and product quality (Nuttall et al., 2017).

Based on wheat quality classification of the National standard of the People's Republic of China (GB/T 17320-2013), the average protein content of wheat grains in Shanxi has reached above $14 \%$ which is in accordance with the protein content of strong-gluten quality, but the average wet gluten content is up to $28 \%-30 \%$ which was between the strong-gluten and middle-gluten range and cannot meet the wheat standard for making bread for which wet gluten content should be $\geq 32 \%$ (Ma et al., 2016). Therefore, in order to further improve the quality of wheat varieties in Shanxi Province, it is necessary to introduce some high-protein and high-wet gluten varieties from other 
regions (Xiyong et al., 2012). Xia et al. (2014) reported that grain qualities such as protein content and wet gluten content of six wheat varieties from Huanghuai wheat region were improved significantly compared to those of local variety Shannong 129 after late sowing in Jinzhong wheat region, Shanxi province. Ma et al. (2016) showed that Wumai $201 \mathrm{~W} 22$ and Wumai 203W2 contain high-protein $(\geq 14 \%)$ with high-gluten $(\geq 32 \%)$ and high-protein $(\geq 14 \%)$ with middle-gluten $(30 \%-32 \%)$, respectively, while the local Shannong 129 contains middle-protein (13.4\%-14\%) with lower-gluten $(<30 \%)$ after late sowing in Jinzhong wheat region. Juanjuan et al. (2016) studied the genetic potential and wheat quality in Jinzhong, Shanxi province and reported that Heixiaomai 031244 was higher-protein and middle-gluten (30-32\%), however, Wumai 202W22 was low-yield with middle-protein (13.4-14.0\%) and lower-gluten, and there was only Jinmai84 which was middle-yield with lower-protein $(\leq 13.05 \%)$ and lowergluten $(\leq 30 \%)$. Shannong 129 of the local breeds was higher-yield with middle-protein and lower-gluten. Besides, Shanxi is also an important livestock and poultry production area, such as pig, cattle, sheep, chick, but feed crops are mainly oats and corn. In order to enrich feed crop resources, it is necessary to introduce some other feed crops, such as rye and triticale.

Soil microbes could be a critical factor affecting grain quality because they are important regulators of plant productivity. The cultivar selection can also affect soil microbial diversity (Nelson et al., 2008; Yang et al., 2016). Therefore, rhizosphere soil microbial diversity was hypothesized to be significantly different among different varieties of Triticeae crops. To validate our hypothesis, in our study, we have chosen ten different varieties of Triticeae crops, which are of high quality and variable in chromosome ploidy, grain color, overwintering, gluten, and source. They include four varieties of common winter wheat (Shannong 129, Yannong 19, Shannong zixiaomai and Heixiaomai 031244), one variety of common half-winter wheat (Huaimai 18), one variety of rye (rye 4R), one variety of triticale (taisi 1), two varieties of common spring wheat (Yumai 34 and Wumai 202w22), and one variety of durum wheat (Yavaros F9). Using the method of PCR-denaturing gradient gel electrophoresis (PCR-DGGE) of the $\mathrm{V} 3$ region of $16 \mathrm{~S}$ or the V1-V2 region of $18 \mathrm{~S}$ ribosomal DNA (rDNA) (Yang et al., 2016), we preliminarily compared the similarity and diversity of rhizosphere soil microbes (bacteria and fungi) in the above Triticeae crops, collected general (occurring in all soils) and specific (occurring in some soils only) bands of their DGGE gel, and then sequenced the $16 \mathrm{~S}$ or $18 \mathrm{~S}$ rDNA fragments to examine the microbial species and to determine detailed microbial community changes among rhizospheric soils of ten Triticeae crop varieties.

\section{Materials and methods}

\section{Field site description}

The experiment was conducted in the experimental field of Shanxi Agricultural University in Taigu County, Shanxi Province, China (Fig. 1). The experimental field is located at $37^{\circ} 25^{\prime} \mathrm{N}$ and $112^{\circ} 35^{\prime} \mathrm{E}$ and continuously planted with winter wheat many years, one time per year. The winter wheat variety Shannong 129, which was bred by Shanxi Agricultural University in 2009, previously had been planting in the experimental field for many years. The field soil was medium loam; soil samples of cultivated horizon $(20 \mathrm{~cm})$ contained total nitrogen of $1.80 \mathrm{~g} \mathrm{~kg}^{-1}$, organic matter of $12.6 \mathrm{~g} \mathrm{~kg}^{-1}$, available $\mathrm{N} 53.6 \mathrm{mg} \mathrm{kg}^{-1}$, available $\mathrm{P} 9.6 \mathrm{mg} \mathrm{kg}{ }^{-1}$ and exchangeable $\mathrm{K}$ 
$137.5 \mathrm{mg} \mathrm{kg}^{-1}$, which were measured by the methods as previously described (Lü et al., 2002; Yang et al., 2016). The winter wheat in the fall and the spring wheat in the spring are planted one time per year in the field.

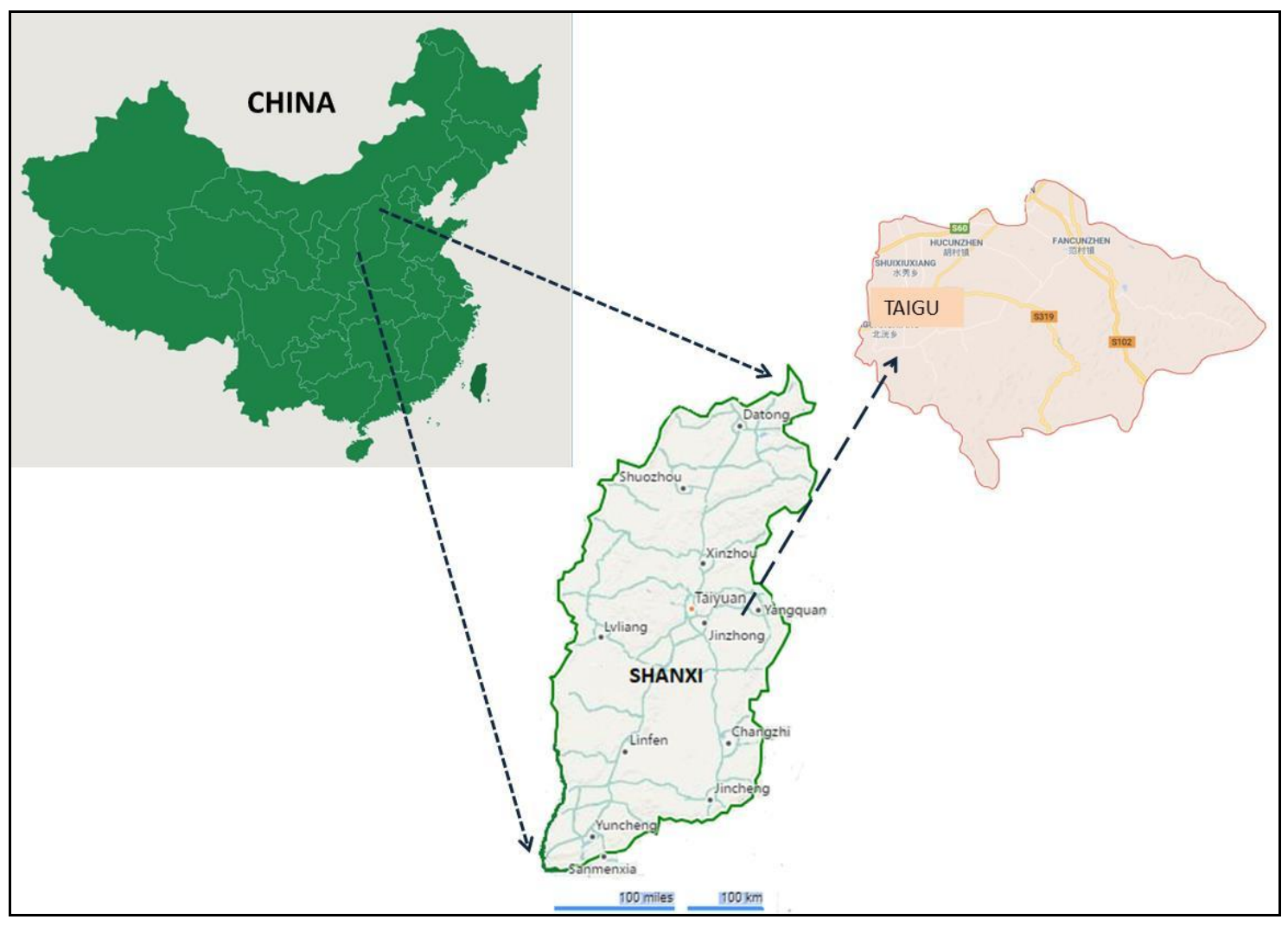

Figure 1. Map of experimental region in China

\section{Triticeae species and varieties}

Four kinds of Triticeae crops, belonging to common wheat, durum wheat, rye and triticale, respectively, were introduced in the experiment. The characteristics of each variety were summarized in Table 1. Common wheat is one of the main food crops planted in Shanxi province and is divided into winter, semi-winter and spring wheat according to vernalization. Winter wheat is often sown in the fall of current year and harvested in the summer of the following year, especially must pass through the vernalization stage (low temperature of $0-5{ }^{\circ} \mathrm{C}$, short-day) and then enter the reproductive growth period (including heading, flowering and grain filling stages). Spring wheat is often sown in spring and harvested in summer this year without overwintering stage. Semi-winter wheat is also sown in fall but its cold resistance is less than winter wheat's. Rye is a feed crop with high yield and high nutritional value, being sown in fall and harvested in summer like winter wheat. Triticale is a new artificial combination species, which is produced by using the sexual hybridization technology and doubling hybrid chromosomes numbers from Triticum and Secale. Durum wheat belongs to Triticum and is usually used for improving wheat grain quality in breeding because both the protein (average 15\%) and wet gluten (average 35\%) content of its grains are higher than those of common wheat (average $14 \%$ and $30 \%$, respectively). Like spring wheat, durum wheat is also sown in spring and harvested in summer. Nine 
different varieties of above the Triticeae crops selected for this study were planted because of their high qualities in the Jinzhong region of Shanxi province, China (Xia et al., 2014; Liu et al., 2015; Ma et al., 2016; Su et al., 2017). The local breeding variety Shannong 129 was chosen as control.

\section{Experimental design}

In the experiment, randomized block design was adopted to plant the ten varieties above mentioned. Ten varieties made up a block group in random order, in triplicate, that is to say, in total three block groups, which were named as $\mathrm{A}, \mathrm{B}$, and $\mathrm{C}$ groups, respectively. The distance between two adjacent blocks was $60 \mathrm{~cm}$, and the distance between two adjacent varieties was $40 \mathrm{~cm}$. Each variety was planted four rows, rowlength $5 \mathrm{~m}$, row-space $20 \mathrm{~cm}$, planting area $4 \mathrm{~m}^{2}(4.20 \mathrm{~m} \times 5 \mathrm{~m})$, planting-depth $5 \mathrm{~cm}$ and planting density 300 grains per row. The seven of winter and semi-winter varieties (Shanong 129, Yannong 19, Shannong zixiaomai, Heixiaomai 031244, rye 4R, Taisi 1 and Huaimai 18) were sown on September 30, 2012, and the remaining three of spring varieties (Yumai 34, Wumai 202w22 and Yavaros F9) were sown on February 26, 2013. During the entire development period, common field management was used for each variety. At the mature stage (June 30, 2013), rhizospheric soil samples from the 0$20 \mathrm{~cm}$ soil layer were taken to complete microbial community diversity analysis for each variety.

\section{Soil sampling}

For the ten varieties of Triticeae crops, soil samples were collected at three different sampling sites of three block groups (A, B and C) at the maturity stage (Fig. 2).

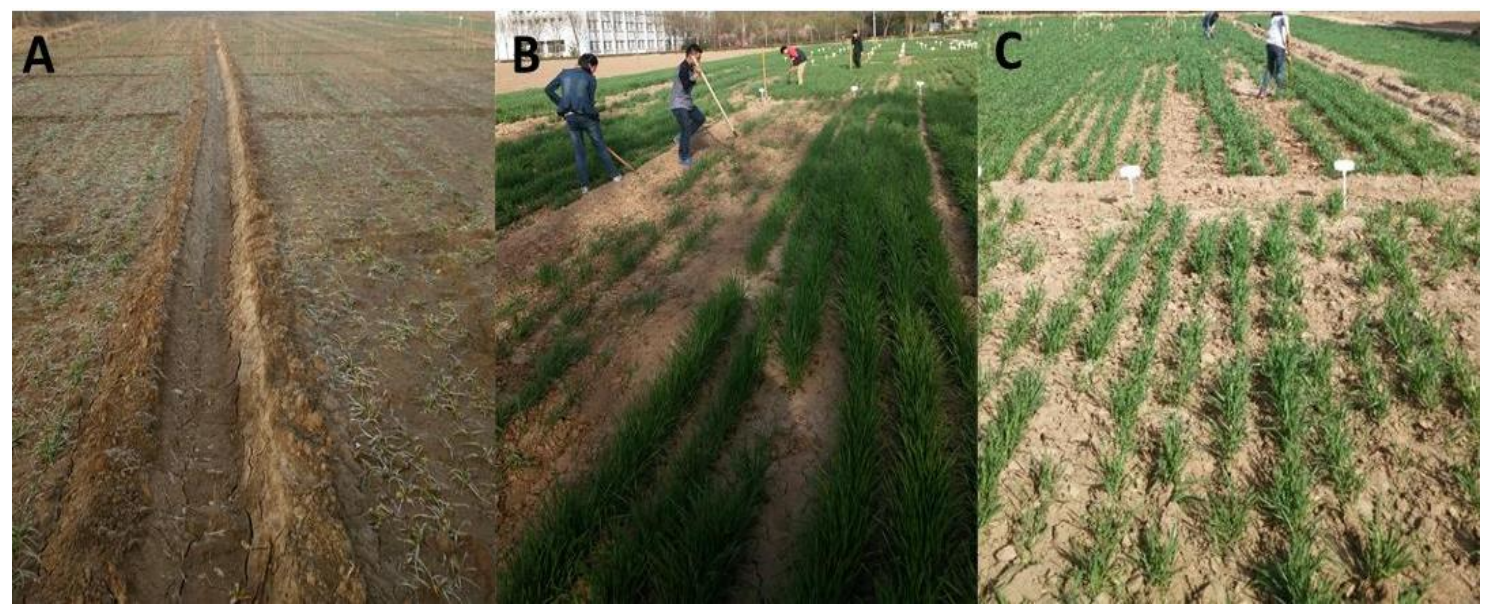

Figure 2. Sampling sites for soil collection at Shanxi province, China

The Triticeae crops having different sowing and flowering time but the maturity time was almost consistent, therefore, samples were collected at maturity stage. Considering the effect of the side row, three random sampling points were chosen from two rows in the middle for each sampling site (such as A) with a minimum distance of $2 \mathrm{~m}$ between individual sampling points. An $8-\mathrm{cm}$ diameter soil auger was used to drill a suitable hole into the ground around the crop roots for the soil samples from the $0-20 \mathrm{~cm}$ layer. In the sterile petri dishes, the roots were taken out and shaken gently to remove non 
rhizospheric soil to collect the soil remaining on the roots as rhizospheric soil. Every variety had nine random single samples of rhizospheric soil. By thoroughly mixed the nine samples to reduce the spatial difference in soil and sieved by a $2 \mathrm{~mm}$ sieve, respectively, the composite samples representing each Triticeae crop variety were obtained, collected in sealed individual plastic bags, and stored at $-20{ }^{\circ} \mathrm{C}$ until DNA extraction was performed in the lab (Table 1).

Table 1. Characteristics and rhizosphere soil samples of ten varieties of several Triticeae crops in the experiment

\begin{tabular}{c|c|c|c|c|c|c}
\hline Crops & Varieties & $\begin{array}{c}\text { Chromosome } \\
\text { ploidy }\end{array}$ & $\begin{array}{c}\text { Grain } \\
\text { color }\end{array}$ & $\begin{array}{c}\text { Varietal } \\
\text { characteristic }\end{array}$ & Source region & $\begin{array}{c}\text { Rhizosphere } \\
\text { soil samples }\end{array}$ \\
\hline $\begin{array}{c}\text { Common } \\
\text { wheat }\end{array}$ & Shannong 129 & Hexaploid & Red & Winter & $\begin{array}{c}\text { Middle of } \\
\text { Shanxi, China }\end{array}$ & S1 \\
\hline $\begin{array}{c}\text { Common } \\
\text { wheat }\end{array}$ & Yannong 19 & Hexaploid & White & Winter & $\begin{array}{c}\text { Shandong, } \\
\text { China }\end{array}$ & S2 \\
\hline $\begin{array}{c}\text { Common } \\
\text { wheat }\end{array}$ & Huaimai 18 & Hexaploid & White & Half-winter & Jiangsu, China & S3 \\
\hline $\begin{array}{c}\text { Common } \\
\text { wheat }\end{array}$ & Yumai 34 & Hexaploid & White & Spring & Henan, China & S4 \\
\hline $\begin{array}{c}\text { Common } \\
\text { wheat }\end{array}$ & Shannong zixiaomai & Hexaploid & Purple & Winter & $\begin{array}{c}\text { Middle of } \\
\text { Shanxi, China }\end{array}$ & S5 \\
\hline $\begin{array}{c}\text { Common } \\
\text { wheat }\end{array}$ & Heixiaomai 031244 & Hexaploid & Black & Winter & $\begin{array}{c}\text { Middle of } \\
\text { Shanxi, China }\end{array}$ & S6 \\
\hline $\begin{array}{c}\text { Common } \\
\text { wheat }\end{array}$ & Wumai 202w22 & Hexaploid & Black & Spring & $\begin{array}{c}\text { South of } \\
\text { Shanxi }\end{array}$ & S7 \\
\hline $\begin{array}{c}\text { Durum } \\
\text { wheat }\end{array}$ & Yavaros F9 & Tetraploid & Red & Spring & Canada & S8 \\
\hline Rye & Rye 4R & Diploid & Black & Winter & Canada & S9 \\
\hline Triticale & Taisi 1 & Octaploid & Red & Winter & England & S10 \\
\hline
\end{tabular}

\section{PCR-DGGE microbial community analysis}

The PCR-DGGE technique, separating the DNA of different sequence by the concentration gradient of the denatured agent of polyacrylamide gel, and providing community composition as well as information about the dominant species in the community by analyzing the sequence of excised bands (Yang et al., 2016), is suitable for investigating the spatiotemporal changes of species population, has the characteristics of repeatability and simple operation, and can be used to analyze multiple samples simultaneously. Therefore, it is feasible to use the PCR-DGGE technique in this experiment. To investigate microbial community diversity in the rhizospheric soil of Triticeae crops, PCR-DGGE) of the V3 region of $16 \mathrm{~S}$ or the V1-V2 region of $18 \mathrm{~S}$ ribosomal DNA (rDNA) was performed. Species of the complex microbial community were assayed by a genotypic fingerprinting approach using the PCR-DGGE technique. Each composite soil sample was divided in triplicate, and then total DNA was extracted directly from the soil according to the E.Z.N.A. ${ }^{\text {TM }}$ Soil DNA Kit protocol (Omega Bio-Tek). 


\section{PCR amplification of $16 S$ rDNA V3 hypervariable region for bacteria}

The PCR amplification of the 16S rDNA V3 hypervariable region for bacteria (about $250 \mathrm{bp}$ PCR product) was performed in $50 \mu \mathrm{L}$ of reaction mixture by universal bacterial specific primers F338-GC CGCCCGCCGCGCGCGGCGGGCGGGGCGGGGGCACGGGGGGCCTACGGGAG GCAGCAG-3') and R518 (5'- ATT ACC GCG GCT GCT GG -3') on a C1000-Touch Thermocycler (Gene Amplification PCR System, Bio-Rad, USA) using the touchdown PCR method, which increases specificity of PCR reactions and uses a cycling program in which the annealing temperature is gradually reduced (e.g. decrease $0.5^{\circ} \mathrm{C} / \mathrm{each}$ cycle). The thermal cycling scheme was as follows: initial denaturation at $94{ }^{\circ} \mathrm{C}$ for $5 \mathrm{~min}, 20$ touchdown cycles of denaturation at $94{ }^{\circ} \mathrm{C}$ for $1 \mathrm{~min}$, annealing at $65{ }^{\circ} \mathrm{C}$ (reduced $0.5{ }^{\circ} \mathrm{C}$ per cycle) for $1 \mathrm{~min}$, and extension at $72{ }^{\circ} \mathrm{C}$ for $3 \mathrm{~min}$, followed by 10 cycles of denaturation at $94{ }^{\circ} \mathrm{C}$ for $1 \mathrm{~min}$, annealing at $55{ }^{\circ} \mathrm{C}$ for $1 \mathrm{~min}$, and extension at $72{ }^{\circ} \mathrm{C}$ for $3 \mathrm{~min}$, and a final extension period at $72{ }^{\circ} \mathrm{C}$ for $10 \mathrm{~min}$. The compositions of the PCR reaction mixture and the examination of the PCR products consulted the reference (Yang et al., 2016) with a minor modification.

\section{PCR amplification of $18 S$ rDNA V1-V2 region for fungus}

Similar to bacteria, the target part of the 18S rDNA V1-V2 region (about 450-bp PCR product), which is the most suitable region for detecting fungal diversities in soil using DGGE analysis, was amplified by universal fungal specific primers Fung-GC (5'CGCCCGCCGCGCCCCGCGCCCGGCCCGCCGCCCCCGCCCCATTCCCCGTTAC CCGTTG-3' and NS1 5'-GTAGTCATATGCTTGTCTC-3'). The PCR mixture compositions were the same as the bacterial fragment amplification above, except for the universal primers $(1 \mu \mathrm{L}$ of Fung-GC $(10 \mu \mathrm{M})$ and $1 \mu \mathrm{L}$ of NS1 $(10 \mu \mathrm{M}))$ and product checks. DNA samples were amplified by PCR using the following thermal cycling scheme: initial denaturation at $94{ }^{\circ} \mathrm{C}$ for $3 \mathrm{~min}, 40$ cycles of denaturation at $94{ }^{\circ} \mathrm{C}$ for $1 \mathrm{~min}$, annealing at $50{ }^{\circ} \mathrm{C}$ for $1 \mathrm{~min}$, and extension at $72{ }^{\circ} \mathrm{C}$ for $1 \mathrm{~min}$, followed by a final extension period at $72{ }^{\circ} \mathrm{C}$ for $10 \mathrm{~min}$.

\section{DGGE analysis}

Gels for the DGGE of PCR products (300 ng) carried out using a D-Code Mutation Detection System instrument (Bio-Rad, USA) were prepared, run for $8.0 \mathrm{~h}$ at $120 \mathrm{~V}$ and $60{ }^{\circ} \mathrm{C}$ in $10 \%$ (w/v) polyacrylamide, and visualized by the UVI Gene Genius Bioimaging System (Figs. 1 and 2) according to the reference (Yang et al., 2016). Soil samples used in the study were labelled as in Table 1.

\section{DGGE gel bands recovery}

Some bands in DGGE gel (bands indicated by yellow arrows in (Figs. 3 and 4), no matter general (occurring in all soils, such as band No. 13 in Fig. 2) or specific (occurring in some soils only, including bands No. 1-15 in (Fig. 3) as well as bands No. 1-12 and 14-15 in (Fig. 4) bands, were identified using direct sequencing of PCR products recovered from the gel by the SK1135 UNIQ-10 Column Kit (Shanghai Sangon Biological Engineering Technology \& Service Co., Ltd., P. R. China). The target genes were re-amplified with the original primer sets (F357 5'CCTACGGGAGGCAGCAG -3', R518 5'- ATTACCGCGGCTGCTGG -3' for 
bacteria; and fungi; 5'-CATTCCCCGTTACCCGTTG-3', NS1: 5'GTAGTCATATGCTTGTCTC-3' for fungi), and the expected fragments (about $250 \mathrm{bp}$ for bacteria and about $450 \mathrm{bp}$ for fungi) were obtained. The PCR mixture compositions and reaction conditions were the same as above. The PCR products were recovered using the SK1131 UNIQ-10 Column Kit. All reactions were performed in triplicate.

\section{Cloning and sequencing}

The target fragments were TA ligated to Takara pMD®18-T vector. According to the methods of published document (Yang et al., 2016), DNA sequencing of one 16S rDNA or 18S rDNA fragment was performed step by step. In the end, we compared these partial 16S and 18S rDNA sequences with sequences deposited in the GenBank database using Blast (http://blast.ncbi.nlm.nih.gov/). The new DNA sequences had been submitted to GenBank with accession numbers MF673132-MF673161.

The DNA sequence results of bacteria and fungi are given in Attachments 1 and 2. The similarity values of BLASTN results are in Table 3 and accession numbers shown in Attachment 3.

\section{Statistical analysis of DGGE patterns}

Digitized DGGE images were analyzed by Quantity One software (Bio-Rad, USA). The Shannon diversity index (H) and Simpson's (D) index as mathematical measurements have been commonly used to characterize species diversity in a community (Du et al., 2016). DNA bands in gels were identified by Quantity One software (Bio-Rad, USA). Both Shannon diversity index (H) and Simpson's index (D) were calculated based on the number and relative intensities of DGGE bands. The Shannon (H) and Simpson's (D) index were calculated as follows:

$$
\begin{gathered}
\mathrm{H}=-\sum\left(P_{i}\right)\left(\ln P_{i}\right), \\
\mathrm{D}=1-\sum P_{i}^{2},
\end{gathered}
$$

where $p_{i}$ is the proportion of $i$ th phylotype.

To further understand the differentiation among DNA fragments from rhizosphere soil samples, the UPGMA (unweighted pair group method with arithmetic means) dendrograms of DGGE band profiles for bacteria and fungus (Figs. 5 and 6 ) were constructed using the clustering algorithm baseetd on the Dice similarity coefficient (Tables 3 and 4). The data of diversity index among ten varieties was statistically analyzed by ANOVA program of SAS9.1.3 software. A probability value (P) of $<0.05$ was considered statistically significant.

\section{Results}

\section{PCR-DGGE analysis of soil samples for ten varieties}

In the DGGE gel, DNA fragments of the same length, but with different base-pair sequences, could be separated (Muyzer et al., 1993). The electrophoresis band pattern provided a profile of microbe diversity in rhizosphere soil samples. It is commonly assumed that these profiles and quantitation of peaks (bands) reflects the structure of the community. Concretely speaking, in each lane of the DGGE gel, the visualized 
intensities of DNA bands could respond to relative microbe biomass, and the number of DNA bands might reflect the genetic diversity of microbe community in rhizosphere soil samples. The greater the band number, the more diverse the microbial community is. These individual bands represented different gene fragments or different stable structural conformations of either the bacterial 16S rDNA V3 hypervariable region or the fungal 18S rDNA V1-V2 region. The relative intensity of each band and its position most likely represent the relative abundance of a particular species in the microbial community. Firstly, PCR-DGGE analysis was performed to investigate the microbe diversity of each Triticeae crop variety. The DGGE profiles indicated different bands' patterns for different soil samples (Figs. 3 and 4). As seen from DGGE profiles of PCR products of $16 \mathrm{~S}$ rDNA V3 region in Figure 3, it was different in the bands' patterns from soil samples S1-S10 of different varieties, such as the location, intensity and number. Some strong and unique bands were observed in bacterial DGGE patterns of some varieties, while they were not detected in other varieties (Fig. 3). For example, Huaimai 18 soil of S3 had bands shown as code number 7, 8 and 10, while other varieties had no such bands. Bands 14 and 6 were observed in Shannong 129 soil of S1 and Yannong 19 soil of S2, respectively. Band 2 was found in rhizosphere soil samples from all crops except Shannong129 (S1). The bands shown as code number 1, 11 and 15 were found in rhizosphere soil samples of Yannong 19, Huaimai 18, and Yumai 34.

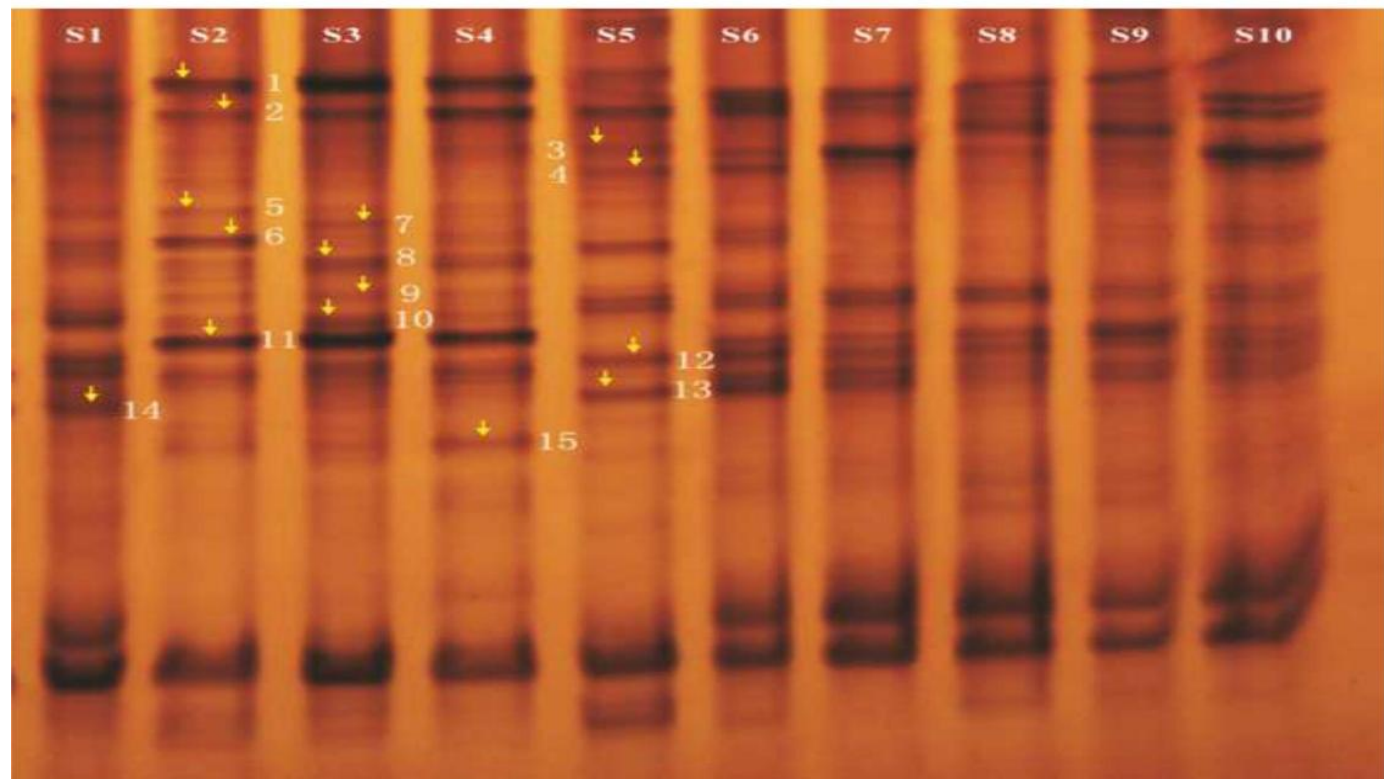

Figure 3. DGGE analysis of bacterial community profiles of $16 \mathrm{~S}$ rDNA PCR amplification products of rhizospheric soil samples S1-S10 of 10 different Triticeae crops

The same situation occurred in fungal DGGE patterns of soil samples of different Triticeae crops. As shown in Figure 4, Yumai 34 soil of S4 was observed to show bands 2 and 8 compared to other Triticeae varieties soil; only Shannong zixiaomai soil of S5 was observed to show bands 1 and 3; band 9 was specific to the rhizosphere soil sample of Huaimai 18; band 13 was observed in all rhizosphere soil samples; Shannong 129 and Yumai 34 did not contain the band labeled as code number 15 (Fig. 4). The results revealed that the compositions of rhizospheric soil microbial communities including both bacteria and fungi were different among the ten varieties of Triticeae crops. 


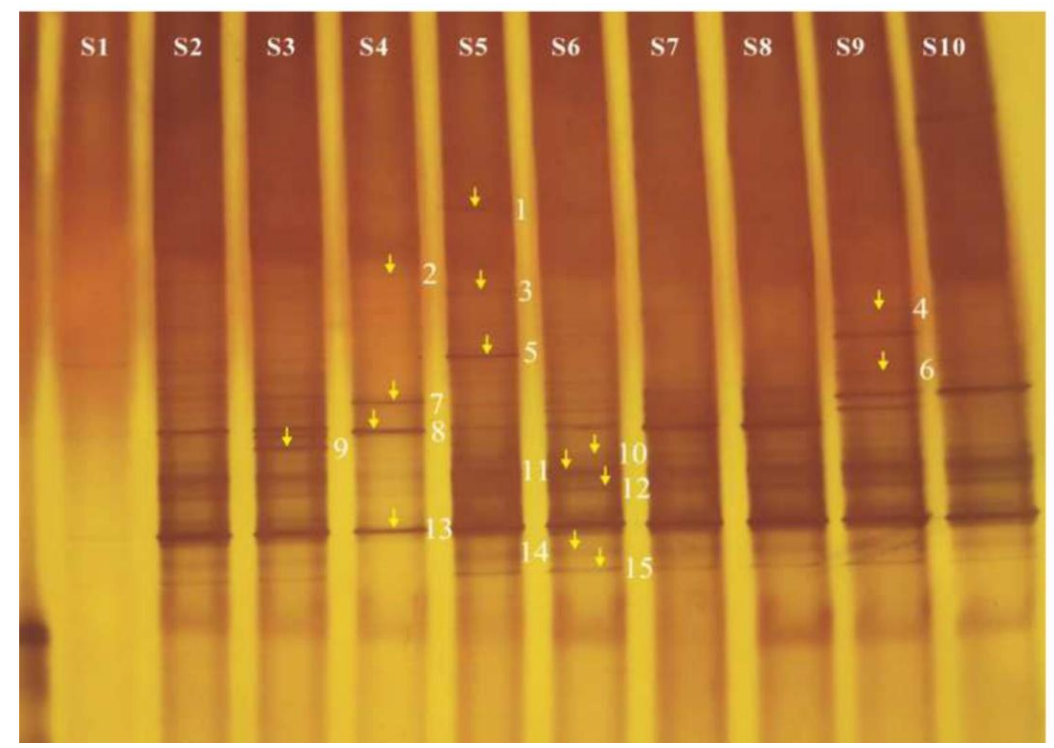

Figure 4. DGGE analysis of fungal community profiles of $18 S$ rDNA PCR amplification products of rhizospheric soil samples S1-S10 of 10 different Triticeae crops

Genetic diversity of rhizospheric soil bacterial and fungal communities in soil samples S1-S10 of different Triticeae crop varieties

To investigate the level of microbial diversity, we used the cluster analysis generated by a UPGMA dendrogram to calculate the diversity indices (Table 2).

Table 2. Bacterial and fungi Simpson's and Shannon's method/Log base of rhizospheric soil samples S1-S10 of different varieties for Triticeae crops

\begin{tabular}{|c|c|c|c|c|c|}
\hline \multirow{2}{*}{$\begin{array}{c}\text { Varieties for } \\
\text { Triticeae crops }\end{array}$} & \multirow{2}{*}{$\begin{array}{l}\text { Rhizosphere } \\
\text { soil samples }\end{array}$} & \multicolumn{2}{|c|}{ Bacteria } & \multicolumn{2}{|c|}{ Fungus } \\
\hline & & $\begin{array}{l}\text { Simpson's } \\
\text { Index }\end{array}$ & $\begin{array}{l}\text { Shannon's } \\
\text { Index }\end{array}$ & $\begin{array}{l}\text { Simpson's } \\
\text { index }\end{array}$ & $\begin{array}{c}\text { Shannon's } \\
\text { index }\end{array}$ \\
\hline Shannong 129 & S1 & $0.665 \pm 0.011 \mathrm{~b}$ & $3.59 \pm 0.06 \mathrm{c}$ & $0.663 \pm 0.009 \mathrm{e}$ & $1.29 \pm 0.04 \mathrm{i}$ \\
\hline Yannong 19 & $\mathrm{~S} 2$ & $0.574 \pm 0.004 \mathrm{~cd}$ & $2.04 \pm 0.06 \mathrm{e}$ & $0.779 \pm 0.008 \mathrm{~b}$ & $4.46 \pm 0.07 \mathrm{~b}$ \\
\hline Huaimai 18 & S3 & $0.587 \pm 0.005 \mathrm{c}$ & $2.85 \pm 0.09 \mathrm{~d}$ & $0.796 \pm 0.003 \mathrm{a}$ & $4.82 \pm 0.02 \mathrm{a}$ \\
\hline Yumai 34 & $\mathrm{~S} 4$ & $0.570 \pm 0.006 \mathrm{de}$ & $2.00 \pm 0.12 \mathrm{e}$ & $0.772 \pm 0.007 \mathrm{~b}$ & $4.25 \pm 0.08 \mathrm{c}$ \\
\hline Shannong zixiaomai & S5 & $0.562 \pm 0.008 \mathrm{e}$ & $1.69 \pm 0.07 \mathrm{~g}$ & $0.684 \pm 0.001 \mathrm{~d}$ & $3.70 \pm 0.07 \mathrm{e}$ \\
\hline Heixiaomai 031244 & S6 & $0.676 \pm 0.017 \mathrm{a}$ & $3.84 \pm 0.06 \mathrm{a}$ & $0.733 \pm 0.010 \mathrm{c}$ & $4.06 \pm 0.05 \mathrm{~d}$ \\
\hline Wumai 202w22 & S7 & $0.563 \pm 0.005 \mathrm{de}$ & $1.52 \pm 0.04 \mathrm{gh}$ & $0.696 \pm 0.007 \mathrm{~d}$ & $2.25 \pm 0.09 \mathrm{~g}$ \\
\hline Yavaros F9 & S8 & $0.552 \pm 0.009 \mathrm{e}$ & $1.45 \pm 0.04 \mathrm{~h}$ & $0.690 \pm 0.006 \mathrm{~d}$ & $2.07 \pm 0.06 \mathrm{~h}$ \\
\hline rye $4 \mathrm{R}$ & S9 & $0.669 \pm 0.014 \mathrm{a}$ & $3.70 \pm 0.06 \mathrm{~b}$ & $0.725 \pm 0.005 \mathrm{c}$ & $3.39 \pm 0.10 \mathrm{f}$ \\
\hline Taisi 1 & S10 & $0.573 \pm 0.004 \mathrm{c} \mathrm{de}$ & $1.78 \pm 0.06 \mathrm{f}$ & $0.722 \pm 0.009 \mathrm{c}$ & $3.31 \pm 0.13 \mathrm{f}$ \\
\hline
\end{tabular}

The indices of all soil samples were represented by the mean values with standard deviation and were compared by Duncan's multiple comparison. Different lowercase letters in the same column indicate significant difference $(\mathrm{P}<0.05)$

Diversity indices of the soil bacterial and fungal communities were significantly different among the varieties of soil samples S1-S10 $(\mathrm{P}<0.05)$ of Triticeae crops. These findings were mostly consistent with band patterns observed in the DGGE profiles (Figs. 3 and 4) and revealed that the diversity of rhizospheric soil bacterial and 
fungal communities was significantly affected by different varieties of Triticeae crops $(\mathrm{P}<0.05)$. Reports have that 'interband' regions were considered as a potential source for less dominant members of natural microbial communities, and indicate that including such members might be a better fit for the use of Shannon index. Our study results showed that the Shannon index of a variety was high and its Simpson index was also high, and the differences of Shannon index between the varieties were greater than those of Simpson index (Table 2).

The Shannon index was more suitable than the Simpson index for reflecting microbial community diversity. Among the ten soil samples in this experiment, Heixiaomai 031244 (S6) had the highest bacterial diversity indices, followed by rye 4R (S9) and Shannong 129 (S1). The lowest diversity was shown in Yavaros F9 (S8) (Table 2). However, in terms of fungal community diversity, Huaimai 18 (S3) had the highest diversity indices, followed by Yannong 19 (S2), Yumai 34 (S4), Heixiaomai 031244 (S6), rye 4R (S9) and Taisi 1 (S10). The lowest level of diversity was exhibited in Shannong 129 (S1). To further understand the differences among microbial community structures of each sample, we constructed a UPGMA dendrogram with the $16 \mathrm{~S}$ rDNA and 18S rDNA fragments (about $250 \mathrm{bp}$ and $450 \mathrm{bp}$, respectively) and community Dice Coefficient for samples S1-S10 (Figs. 5 and 6, Tables 3 and 4).

Table 3. The Dice coefficient calculated by DGGE profiles of bacterial $16 S$ rDNA PCR amplification products from rhizospheric soil samples S1-S10 from different varieties of several Triticeae crops

\begin{tabular}{c|c|c|c|c|c|c|c|c|c|c}
\hline Lane & S1 & S2 & S3 & S4 & S5 & S6 & S7 & S8 & S9 & S10 \\
\hline S1 & 1.000 & & & & & & & & & \\
S2 & 0.544 & 1.000 & & & & & & & & \\
S3 & 0.443 & 0.666 & 1.000 & & & & & & & \\
S4 & 0.489 & 0.691 & 0.645 & 1.000 & & & & & & \\
S5 & 0.442 & 0.329 & 0.254 & 0.342 & 1.000 & & & & & \\
S6 & 0.534 & 0.645 & 0.461 & 0.601 & 0.536 & 1.000 & & & & \\
S7 & 0.415 & 0.499 & 0.412 & 0.567 & 0.433 & 0.776 & 1.000 & & & \\
S8 & 0.424 & 0.329 & 0.278 & 0.339 & 0.388 & 0.462 & 0.543 & 1.000 & & \\
S9 & 0.299 & 0.353 & 0.390 & 0.284 & 0.301 & 0.277 & 0.260 & 0.455 & 1.000 & \\
S10 & 0.355 & 0.436 & 0.404 & 0.474 & 0.343 & 0.447 & 0.582 & 0.602 & 0.363 & 1.000 \\
\hline
\end{tabular}

Table 4. The Dice coefficient calculated by DGGE profiles of bacterial 18S rDNA PCR amplification products from rhizosphere soil samples S1-S10 from different varieties of several Triticeae crops.

\begin{tabular}{c|c|c|c|c|c|c|c|c|c|c}
\hline Lane & S1 & S2 & S3 & S4 & S5 & S6 & S7 & S8 & S9 & S10 \\
\hline S1 & 1.000 & & & & & & & & & \\
S2 & 0.159 & 1.000 & & & & & & & & \\
S3 & 0.337 & 0.558 & 1.000 & & & & & & & \\
S4 & 0.000 & 0.352 & 0.186 & 1.000 & & & & & & \\
S5 & 0.248 & 0.418 & 0.562 & 0.265 & 1.000 & & & & & \\
S6 & 0.065 & 0.342 & 0.498 & 0.349 & 0.519 & 1.000 & & & & \\
S7 & 0.000 & 0.151 & 0.299 & 0.247 & 0.200 & 0.453 & 1.000 & & & \\
S8 & 0.245 & 0.255 & 0.445 & 0.065 & 0.328 & 0.331 & 0.461 & 1.000 & & \\
S9 & 0.220 & 0.358 & 0.417 & 0.118 & 0.365 & 0.332 & 0.547 & 0.480 & 1.000 & \\
S10 & 0.219 & 0.217 & 0.191 & 0.081 & 0.222 & 0.128 & 0.205 & 0.561 & 0.415 & 1.000 \\
\hline
\end{tabular}


Even though the diversity indices of microbial communities in some rhizospheric soil samples such as S9 and S10 in the fungus community were similar to each other, as seen in Table 2, the population structures of microorganisms in these soil samples were different as indicated in Figure 5 or Figure 6. In the bacterial community of rhizospheric soil samples, five main clusters were detected in the condition of a Dice Coefficient of 0.53 (Fig. 5). in the condition of a Dice Coefficient of 0.78, only S6 (Heixiaom 031244) and S7 (Wumai 202W22) were clustered into a group (Fig. 5). The two varieties were black and high-gluten common wheat, but S6 is winter wheat but S7 is spring wheat. In the condition of a Dice Coefficient of 0.69, S2 (Yannong 19) and S4 (Yumai 34) were also clustered into a group. The two varieties were white and highgluten common wheat, but $\mathrm{S} 2$ is winter wheat but $\mathrm{S} 4$ is spring wheat. In the condition of a Dice Coefficient of 0.66, S2, S4 and S3 (Huaimai 18) were further clustered into a group. Huaimai 18 was a white, middle-gluten and half-winter common wheat variety. In the same manner, in the condition of a Dice Coefficient of 0.53, the above-mentioned five varieties were clustered a group. The control of Shannong 129 (red and middlegluten) was significant different with above-mentioned five varieties in the bacteria community structure. It inferred that bacteria community structure of wheat varieties could be related with grain color as well as grain quality. Besides, in the condition of a Dice Coefficient of 0.60, the durum wheat S8 (Yavaros F9) and triticle S10 (Taisi 1) were clustered into a group.

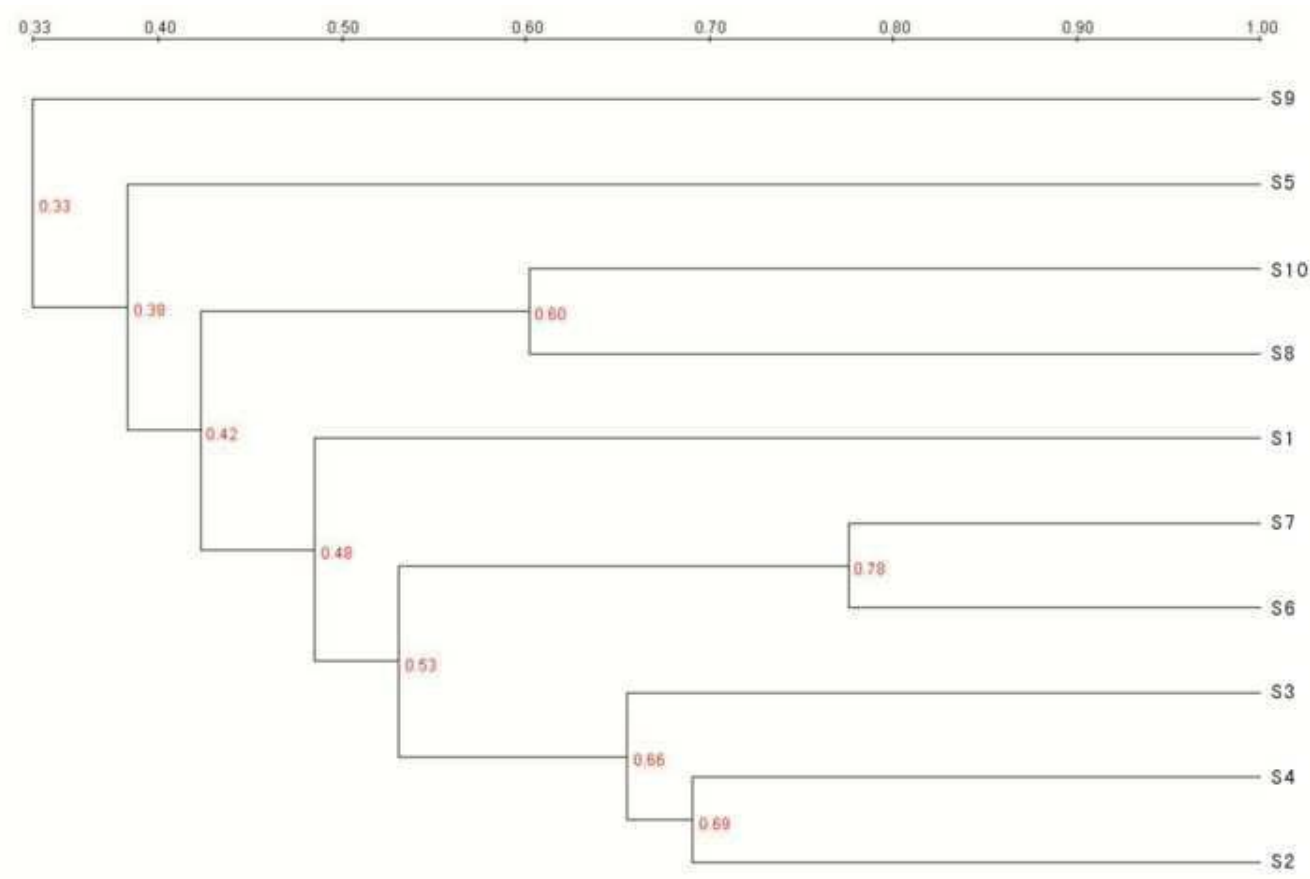

Figure 5. UPGMA dendrogram constructed with DGGE profiles of bacterial 16S rDNA PCR amplification products from rhizospheric soil samples $S 1$-S10 from different varieties of several Triticeae crops

So, in the similarity level of 0.53 , five main clusters were detected. One cluster was found in S3, S2, S4, S6 and S7. Another cluster was observed in S8 and S10. Besides, S9 (rye 4R), S5 (Shannong zixiaomai) and S1 (Shannong 129) stood in three clusters, 
respectively. However, in terms of a Dice Coefficient of 0.48, S1, S2, S3, S4, S6 with $\mathrm{S} 7$ could form a new cluster. If the Dice Coefficient was 0.42 , the above-mentioned new cluster and S8 as well as S10 furthermore composed a bigger cluster. Till a Dice Coefficient of 0.33 , all of ten varieties stood in only one cluster. On the contrary, when the Dice Coefficient was greater than 0.78, ten varieties had 10 clusters. Similarly, in the condition of a Dice Coefficient of 0.51, six main clusters were found in the fungal community of rhizospheric soil samples (Fig. 6). These included a cluster formed by S6 and S5 with S3, a cluster shared by S9 and S7, a cluster containing S8 and S10, and else three clusters formed by S1, S2 and S4, respectively. The larger the Dice coefficient, the more clusters. In contrast, the smaller the Dice coefficient, the less clusters. When the Dice Coefficient was 0.44, S2, S3, S5 \& S6 formed a cluster. When the Dice Coefficient was 0.39, S7, S8, S9 \& S10 form a cluster. When the Dice Coefficient was 0.29 , above mentioned the two clusters formed a new cluster. Ten varieties were clustered into 10 classes when the Dice Coefficient was greater than 0.56 (Fig. 6). Just the opposite, ten varieties were clustered into one class when the Dice Coefficient was less than 0.17 . Therefore, the changes in bacterial and fungal community structure were distinct in different varieties of Triticeae crops.

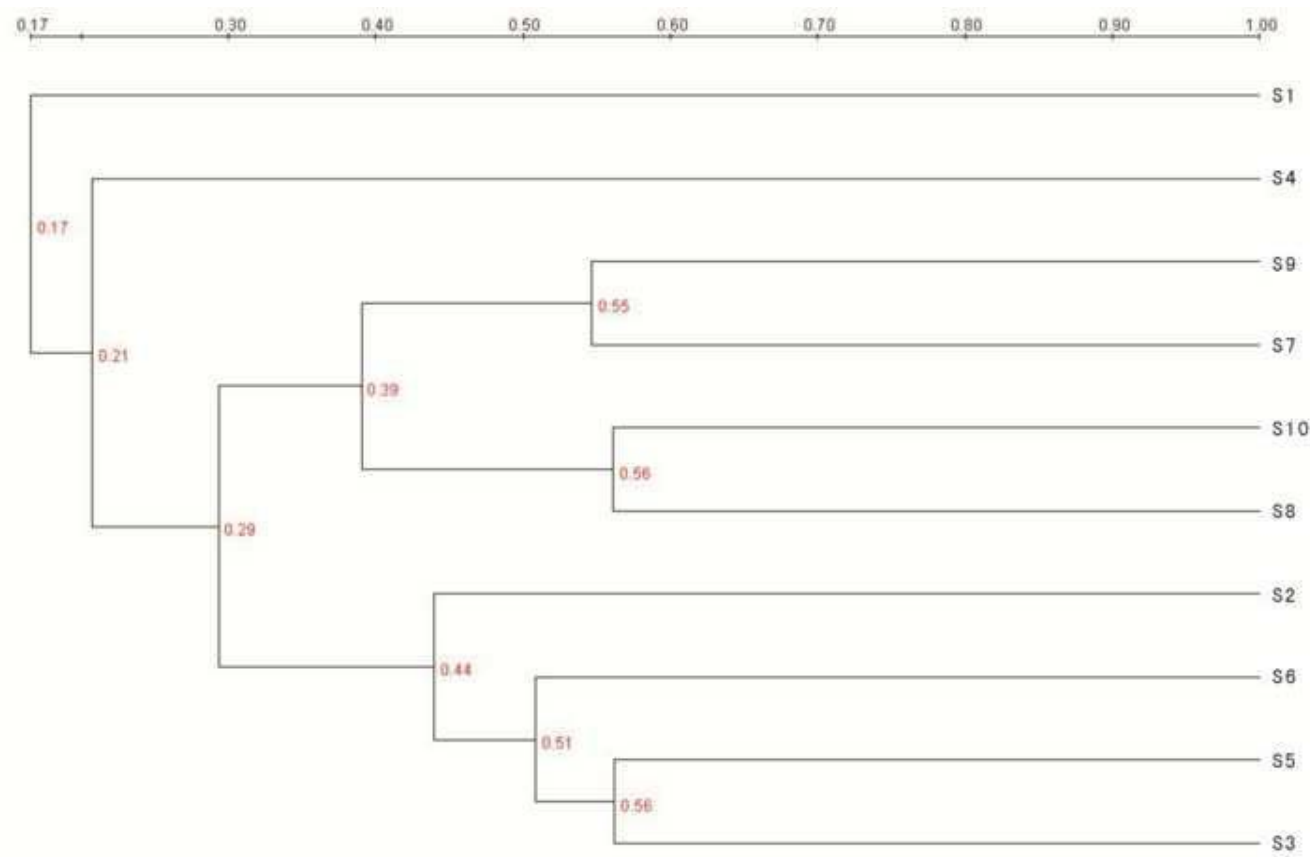

Figure 6. UPGMA dendrogram constructed with DGGE profiles of bacterial 18S rDNA PCR amplification products from rhizosphere soil samples $\mathrm{S1-S10}$ from different varieties of several Triticeae crops

\section{Bacterial and fungal community changes in different rhizospheric soil samples}

To identify the microbial species in each sample, 15 common and specific excised bands were selected from bacterial and fungi DGGE gels of rhizosphere soil samples, respectively (Figs. 3 and 4). The PCR product was recovered from each excised band. Following the sequencing of all PCR products, the sequences obtained were compared with public DNA database sequences by BLASTN on the NCBI web server. The results of sequence comparisons were shown in Tables 5 and 6. 
Table 5. Identification of bacteria species for fifteen bands sequenced from rhizosphere soil samples S1-S10 of different varieties -from several Triticeae crops

\begin{tabular}{c|c|c|c|c}
\hline $\begin{array}{c}\text { Code number of } \\
\text { bands in Fig. 3 }\end{array}$ & $\begin{array}{c}\text { Accession } \\
\text { number in } \\
\text { NCBI }\end{array}$ & V3 Region & $\begin{array}{c}\text { Similarity } \\
(\mathbf{\%})\end{array}$ & Bacterium identification \\
\hline 1 & MF673132 & $170 \mathrm{bp}$ & 88.3 & Uncultured alpha proteobacterium \\
2 & MF673133 & $190 \mathrm{bp}$ & 93.3 & Flavobacterium phragmitis \\
3 & MF673134 & $188 \mathrm{bp}$ & 85.1 & Uncultured bacterium \\
4 & MF673135 & $189 \mathrm{bp}$ & 92.3 & Uncultured Sphingobacteriales bacterium \\
5 & MF673136 & $195 \mathrm{bp}$ & 90.4 & Uncultured Acidobacteria bacterium \\
6 & MF673137 & $188 \mathrm{bp}$ & 92.7 & Uncultured bacterium \\
7 & MF673138 & $195 \mathrm{bp}$ & 78.8 & Uncultured bacterium \\
8 & MF673139 & $189 \mathrm{bp}$ & 97.8 & Uncultured bacterium \\
9 & MF673140 & $194 \mathrm{bp}$ & 93 & Uncultured gamma proteobacterium \\
10 & MF673141 & $189 \mathrm{bp}$ & 91.3 & Uncultured bacterium \\
11 & MF673142 & $196 \mathrm{bp}$ & 88.9 & Uncultured bacterium \\
12 & MF673143 & $195 \mathrm{bp}$ & 100 & Pantoea sp. \\
13 & MF673144 & $195 \mathrm{bp}$ & 91.5 & Uncultured Acidobacteria bacterium \\
14 & MF673145 & $170 \mathrm{bp}$ & 88.4 & Uncultured Chloroflexi bacterium \\
15 & MF673146 & $170 \mathrm{bp}$ & 85.4 & Bdellovibrio sp. \\
\hline
\end{tabular}

Table 6. Identification of fungus for fifteen bands sequenced from rhizospheric soil samples S1-S10 of different varieties from several Triticeae crops

\begin{tabular}{c|c|c|c|c}
\hline $\begin{array}{c}\text { Code number of } \\
\text { bands in Fig. }\end{array}$ & $\begin{array}{c}\text { Accession number in } \\
\text { NCBI }\end{array}$ & V1-V2 Region & $\begin{array}{c}\text { Similarity } \\
(\mathbf{\%})\end{array}$ & Fungal identification \\
\hline 1 & MF673147 & $351 \mathrm{bp}$ & 99 & Uncultured Eukaryote clone \\
2 & MF673148 & $347 \mathrm{bp}$ & 99 & Xylariales sp. \\
3 & MF673149 & $359 \mathrm{bp}$ & 99 & Uncultured fungus \\
4 & MF673150 & $354 \mathrm{bp}$ & 98 & Uncultured Eukaryote \\
5 & MF673151 & $361 \mathrm{bp}$ & 97 & Xenillus tegeocranus \\
6 & MF673152 & $354 \mathrm{bp}$ & 99 & Balen uncultured Eukaryote \\
7 & MF673153 & $392 \mathrm{bp}$ & 99 & Uncultured fungus \\
8 & MF673154 & $378 \mathrm{bp}$ & 93 & Uncultured Eukaryote \\
9 & MF673155 & $362 \mathrm{bp}$ & 98 & Nabis ferus \\
10 & MF673156 & $399 \mathrm{bp}$ & 99 & Uncultured Eukaryote \\
11 & MF673157 & $354 \mathrm{bp}$ & 98 & Uncultured Eukaryote \\
12 & MF673158 & $348 \mathrm{bp}$ & 99 & Malbranchea cinnamomea \\
13 & MF673159 & $399 \mathrm{bp}$ & 99 & Uncultured Eukaryote \\
14 & MF673160 & $399 \mathrm{bp}$ & 99 & Uncultured Eukaryote \\
15 & MF673161 & $399 \mathrm{bp}$ & 99 & Uncultured Eukaryote \\
\hline
\end{tabular}

Digitized DGGE images were analyzed by Quantity One software (Bio-Rad, USA). The software can detect the presence or absence of individual bands in all lanes by binary matrix. In total, 30 detectable microbial species were identified, each band representing a different microbial species. The results indicated that some bacteria or 
fungi were detected only in certain crops. For example, uncultured Chloroflexi bacterium was detected in Shannong 129 (S1), while uncultured Sphingobacteriales bacterium was detected in Shannong zixiaomai (S5) and Heixiaomai 031244 (S6) only. Nabis ferus and Xylariales sp. were detected only in the rhizosphere soils of Huaimai 18 (S3) and Yumai 34 (S4), respectively. Xenillus tegeocranus was detected in Shannong 129 (S1), Yannong 19 (S2), Huaimai 18 (S3), and Shannong zixiaomai (S5), but not detected in the rhizosphere soils of other samples. By identifying the microbial species from different samples, our research demonstrated that the effects of different Triticeae crops on bacterial and fungal community diversity in rhizospheric soils were obvious.

In addition, we found some common bands in soil samples of some different varieties, which indicated there were similarities among the populations of microorganisms that existed in these rhizospheric soils. In the bacterial community, there was one common band coded the number of 2 (Flavobacterium phragmitis) in other nine varieties except Shannong 129 (Fig. 3). The else bands were specific in some varieties. For example, the uncultured alpha proteobacterium (band code 1 in Fig. 3), Flavobacterium phragmitis (band code 2 in Fig. 3), uncultured bacterium (band code 11 in Fig. 3), and Bdellovibrio sp. (band code 15 in Fig. 3) were commonly found in rhizospheric soil samples of common wheat crops, including Yannong 19, Huaimai 18 and Yumai 34 (S2, S3 and S4 in Fig. 3, respectively). As for the fungal community, there was only one common band coded the number of 13 (uncultured Eukaryote) in all soil samples (Fig. 4). The uncultured Eukaryote (band code 15 in Fig. 4) was common across all crops except Shannong 129 and Yumai 34 samples (S1 and S4 in Fig. 4, respectively). Xenillus tegeocranus (band code 5 in Fig. 4) was found in rhizospheric soil samples of common wheat crops, including Shannong 129, Yannong 19, Huaimai 18 and Shannong zixiaomai (S1, S2, S3 and S5 in Fig. 4, respectively). These common microorganisms indicated that there were some shared characteristics among wheat varieties.

\section{Discussion}

The climate features of Shanxi province provide natural and long-standing advantages such as adequate sunlight, moderate mean temperature, large temperature difference between day and night and abundant seed resources for wheat production (Tian et al., 2013). However, drought, a major Shanxi's climate characteristic, on the one hand is beneficial to accumulate protein during grain filing period, and on the other hand is responsible to limit the growth and development of wheat and has resulted in a continuously decreasing planting area of wheat in recent years. The planting area of wheat is currently about 720,000 hectares in Shanxi province, which is not enough to meet market demand. In addition, Shanxi wheat is supposed to contain the protein content of more than $14 \%$ on the average, however its wet-gluten content (28\%-30\% on the average) is lower than that of a large quantity of high quality wheat flour (more than $30 \%$ ) for processing bread or dumpling. Therefore, it is necessary to introduce highquality wheat varieties and improve local wheat variety quality for meeting consumer demand. In addition, the Shanxi provincial government has proposed to adjust the agricultural planting structure, which is to reduce the planting area of corn and increase that of feed crops to develop livestock and poultry production.

Previous evidence has shown that wheat cultivars were involved in shaping the rhizosphere by differentially altering the bacterial community (Aaron et al., 2017). The 
differences in microbial communities observed on different wheat lines showed that wheat breeding could affect rhizospheric communities (Aaron et al., 2017). Yang ZP (one of the authors) had studied the number of rhizosphere soil microbial populations (including bacterial, fungi and actinomycetes) with that of non-rhizosphere soil of 24 crops in north China using the plate culture method. The results revealed that the microbial population of rhizosphere soil was significantly higher than that of nonrhizosphere soil, which was consistent with previous studies (Lou, 1962; Chen, 1990; Takuya, 1990). Besides, in the previous studies by author, 120 varieties from different wheat areas were introduced and planted to Jinzhong wheat area of Shanxi province. Some of the varieties, which were suitable for local ecological climatic conditions and of higher yield-quality than others were selected. For reasons mentioned above, in this experiment, rhizosphere soil was regarded as research object to compare the differences between the introduced varieties from other wheat region and local varieties of Shanxi in rhizosphere soil microbial diversity. Triticeae varieties including nine introduced high-quality wheat / rye / triticale varieties and one local variety (Shannong 129 as control) were selected for preliminarily investigating rhizospheric soil bacterial and fungal community diversity in the Jinzhong region. This study was also conducted for providing theoretical basis for further analyzing the correlation of these indices with grain protein as well as wet-gluten contents to evaluate whether rhizospheric soil microbial community diversity can be used as an accessory ecological indicator on the basis of grain yield and quality for screening varieties. Shannong 129 is a local breeding late maturity winter wheat variety belongs to the northern area of China, and planted widely in the Shanxi wheat region region and fit to the local ecological environment conditions. The other varieties were introduced from other different wheat production regions. In order to expand Triticeae crop resources in Shanxi province, these high quality Triticeae crops were introduced and further investigated their microbial community structures compared with Shannong 129.

Rhizospheric soil is of great importance to plant health and soil fertility. The plant can affect its rhizospheric microbial communities by releasing root exudates (Glick, 1995; Kourtev et al., 2003; Andersen and Winding, 2004;), which are made up of saccharides, organic acid, amino acid, phenolic compound etc (Xiong et al., 2002). The amount and types of root exudates as well as allelopathy differ between crop species. Root exudates could provide a large amount of nutritional energy, stimulate speciesspecific shifts in the soil microbial community, and make changes to microbial community distribution (Xiong et al., 2002; Welbaum et al., 2004; Singh et al., 2007; $\mathrm{Xu}$ et al., 2009; van Dam and Bouwmeester, 2016). A general role for root exudates is becoming evident in repelling or attracting pathogenic or beneficial organisms, inhibiting growth of competing plant species, and altering soil properties (Bais et al., 2006; Weston et al., 2012). For instance, in terms of three hydroponic plants including Ipomoea aquatica, Chlorophytum comosum and Oenanthe javanica, the effects of organic acid in their root exudates on bacteria were not different, a positive effect on some bacteria, such as ammonifying and denitrifying bacteria and an inhibitory effect on others such as nitrobacteria and nitrosobacteria (Zhu and Cheng, 2011).

Previous studies have showed that plants could "shape" the microbial communities in their rhizosphere by attracting beneficial microorganisms that in turn could suppress the growth of pathogenic microbes either through direct competition or by priming the plant's own defenses (Marschner et al., 2004; Miao et al., 2004; Doornbos et al., 2012; Aaron et al., 2017; Schlemper et al., 2017). In our study, it was founded that there were 
differences in the community structures of rhizospheric soil organisms (Figs. 3 and 4) and the diversity indices (Table 2) among wheat varieties, indicating that different varieties of wheat could obviously cause shifts in the composition of dominant populations about rhizospheric microbial communities through DGGE profiles. This conclusion is consistent with previous research (Miao et al., 2004), which showed that numbers of three main species of rhizospheric microbes were much more different after planting different crops on unused soil $2 \mathrm{~m}$ below ground.

Generally thought is that the larger the Shannon's index, the more diverse will be the components of microbial population. Similarly, the larger the Simpson's index, the richer will be the number of microbial population. Our results indicated that the Shannon's index and Simpson's index of Heixiaomai 031244 were highest among the bacterial communities in rhizospheric soils of ten varieties $(\mathrm{P}<0.05)$. This suggested that Heixiaomai 031244 was the most beneficial variety for improving the diversity and abundance of bacterial communities in rhizospheric soils. The second variety was rye 4R. Similarly, the Shannon's index and Simpson's index of Huaimai 18 the highest among the fungal communities in rhizospheric soils of ten varieties $(\mathrm{P}<0.05)$. Huaimai 18 was the most beneficial variety for increasing the diversity and abundance of fungal communities in rhizospheric soils, followed by Yannong 19 and Yumai 34. This suggests that Heixaomai 031244 and Huaimai 18 could be the two best species of seven common wheat varieties introduced into the Jinzhong region of Shanxi province according to Shannon's and Simpson's indexes. The rye 4R was second only to Heixiaomai 031244 in terms of bacterial community diversity. Yannong 19 and Yumai 34 were just behind Huaimai 18 in terms of fungal community diversity. It could be introduced to the Jinzhong region as a feed crop in planting structure adjustment.

Microbial species recognition by cloning and sequencing 16S rDNA or 18S rDNA fragments showed that crop species could stimulate specific microbial species while also causing the loss of others, thereby affecting rhizospheric soil microbial communities (Yang et al., 2016). Our study observed significant stimulation of uncultured bacterium (code No. 8, 7 and 10 in Table 5, respectively) and Nabis ferus (code No. 9 in Table 6), as well as the loss of uncultured Sphingobacteriales bacterium (code No. 4 in Table 5) and Xylariales sp. (code No. 2 in Table 6) in Huaimai 18. In addition, our studies hinted a relatively strong species-specific pattern on rhizospheric soil microbial community structure. Uncultured Chloroflexi bacterium was only found in the rhizosphere soil growing Shannong 129. Uncultured alpha proteobacterium, Flavobacterium phragmitis, uncultured bacterium, and Bdellovibrio sp. were observed in common wheat including Yannong 19, Huaimai 18 and Yumai 34. Uncultured eukaryote (code No. 13 in Table 6) was found in all experimental samples. The wheat cultivar-associated microbes identified in this work could provide beneficial services to their hosts, such as the utilization of organic matter, the degradation of hydrocarbons, and the cycling of respiratory sulfur and nitrogen (Chen et al., 2016; Dombrowski et al., 2017). Observable differences in microbial species of Triticeae crops in the present work could be related to root exudates which select and increase microbes associated with mineral mobilization and nutrient responsive metabolisms, such as nitrogen, sulfur and phosphorus (Aaron et al., 2017). Root exudates are intrinsic factors of rhizospheric effects. There is evidence to suggest that microbes are recruited through root exudates, and the greatest release may occur during the reproductive stages (Zhang et al., 2009; Lakshmanan et al., 2013). For example, Neal et al. (2012) demonstrated a central role in root exudates of maize, as a semiochemical below ground for recruitment of plant- 
beneficial rhizobacteria during the relatively young and vulnerable growth stages of maize. Plant hosts could benefit from these microbes with improved growth, drought and salt tolerance, and protection against soilborne pathogens (Kasim et al., 2013; Glick et al., 2014; de Boer et al., 2015). More interestingly, many uncultured organisms were observed when these Triticeae crop varieties were introduced into the Jinzhong region. In that way, in the course of wheat production, what might be the material cycle process that these specific microbial species or uncultured organisms could be mainly involved in? What would be dominant microbial populations? These issues will be further discussed in the future.

It is worth mentioning that the rhizospheric bacterial diversity of Shannong 129 was higher than that of Huaimai 18 (S3) or Yannong 19 (S2), while fungal diversity was much lower as above mentioned (Table 2). However, our previous studies showed that the grain qualities of Shannong 129 were lower, but its grain yield was higher than that of Yannong 19, whereas both the grain yield and qualities of Shannong 129 were higher than those of Huaimai 18. Considering Huaimai 18 and Yannong 19 have more than 60\% similarity in bacterial community structure and a similar quality of grain, we speculate that various dominant and functional organisms enhanced in these two varieties (Uncultured alpha proteobacterium, Flavobacterium phragmitis, uncultured bacterium, Pantoea sp., Bdellovibrio sp., Xenillus tegeocranus, and uncultured eukaryote) imply a potential relationship between the yield increase of crops and microbial diversity.

\section{Conclusion}

Our study highlighted that variation of rhizospheric soil microbial community diversity is related to different Triticeae varieties. Among the ten experimental varieties, Heixiaomai 031244 was the most beneficial to improving the diversity and abundance of bacterial communities in rhizospheric soils, and Huaimai 18 was the most beneficial to increasing the diversity and abundance of fungal communities in rhizospheric soils. Different wheat varieties across wheat regions could induce an increase in some functional and uncultured rhizospheric soil organisms, such as uncultured alpha proteobacterium, Flavobacterium phragmitis, uncultured bacterium, Bdellovibrio sp., uncultured Sphingobacteriales bacterium, uncultured Acidobacteria bacterium, Nabis ferus and uncultured Eukaryote, suggesting some potential relationship between crop yield increase and microbes in new wheat varieties when compared with local original wheat variety. Our study strongly suggested that Huaimai 18, Yannong 19, and Heixiaomai 031244 could be considered for introduction to the Jinzhong region to develop high quality wheat variety resources for Shanxi. Additionally, rye $4 \mathrm{R}$ could be introduced to the Jinzhong region as a feed crop in planting structure adjustment. Further studies should be conducted to examine the exact mechanisms of these uncultured rhizospheric organisms and their interactions with specific crop species. Further to find whether these microorganisms affect grain quality formation and accumulation will be discussed in a follow-up study.

Acknowledgements. This study was supported by the National Key Technology R\&D Program of China (2015BAD23B04-2), National Natural Science Foundation of China (31101113), Special Funds for Scientific Research on Public Causes (201503120), Research Project Supported by Shanxi Scholarship Council of China (2015-Key 4), fund for Shanxi "1331 Project", Earmarked Fund for Modern Agroindustry Technology Research System (CARS-03-01-24), Shanxi Youth Fund (20031047), and Shanxi Agricultural University Post-doctoral Fund (No. 112124). 


\section{REFERENCES}

[1] Aaron, K. M., Chuntao, Y., Scot, H. H. (2017): Community structure, species Variation, and potential functions of rhizosphere-associated bacteria of different winter wheat (Triticum aestivum) cultivars. - Frontiers in Plant Science 8: 132.

[2] Acosta-Martínez, V., Burow, G., Zobeck, T. M., Allen, V. G. (2010): Soil microbial communities and function in alternative systems to continuous cotton. - Soil Science Society of America Journal 74: 1181-1192.

[3] Aira, M., Gomez-Brandon, M., Lazcano, C., Bååth, E., Domínguez, O. (2010): Plant geno-type strongly modifies the structure and growth of maize rhizosphere microbial communities. - Soil Biology and Biochemistry 42: 2276-2280.

[4] Andersen, K. S., Winding, A. (2004): Non-target effects of bacterial biological control agents on soil Protozoa. - Biology and Fertility of Soils 40: 230-236.

[5] Bais, H. P., Weir, T. L., Perry, L. G., Gilroy, S., Vivanco, J. M. (2006): The role of root exudates in rhizosphere interations with plants and other organisms. - Annual Review of Plant Biology 57: 233-266.

[6] Brock, T. D. (1987): The study of microorganisms in situ: progress and problems. Symposium of the Society for General Microbiology 41: 1-17.

[7] Buyer, J. S., Teasdale, J. R., Roberts, D. P., Zasada, I. A., Maul, J. E. (2010): Factors affecting soil microbial community structure in tomato cropping systems. - Soil Biology and Biochemistry 42: 831-841.

[8] Chen, J., Han, Y., Wang, Y., Gong, B., Zhou, J., Qing, X. (2016): Start-up and microbial communities of a simultaneous nitrogen removal system for high salinity and high nitrogen organic wastewater via heterotrophic nitrification. - Bioresource Technology 216: 196-202.

[9] Chen, W. X. (1990): Soil and Environment Microbiology (1st ed.). - Beijing Agricultural University Press, Beijing, pp. 202-204 (in Chinese).

[10] de Boer, W., Hundscheid, M. P., Klein, G. P. J., de Ridder-Duine, A. S., Thion, C., van Veen, J. A., et al. (2015): Antifungal rhizosphere bacteria can increase as response to the presence of saprotrophic fungi. - PLos One 10(9): e0137988.

[11] Dombrowski, N., Seitz, K. W., Teske, A. P., Baker, B. J. (2017): Genomic insights into potential interdependencies in microbial hydrocarbon and nutrient cycling in hydrothermal sediments. - Microbiome 5(1): 106.

[12] Doornbos, R. F., van Loon, L. C., Bakker, P. A. (2012): Impact of root exudates and plant defense signaling on bacterial communities in the rhizosphere. A review. - Agronomy for Sustainable Development 32(1): 227-243.

[13] Doran, J. W., Zeiss, M. R. (2000): Soil health and sustainability: managing the biotic component of soil quality. - Applied Soil Ecology 15: 3-11.

[14] Du, Y. X., Xie, B. M., Cai, H. S., Tang, L., Guo, C. H. (2016): Structural and functional diversity of rhizosphere microbial community of nine plant species in the Daqing Salinealkali soil region. - Acta Ecologica Sinica 3: 740-747.

[15] FAOSTAT (2017): http://www.fao.org/faostat.

[16] Glick, B. R. (1995): The enhancement of plant growth by free-living bacteria. - Canadian Journal of Microbiology 41: 109-117.

[17] Glick, B. R. (2014): Bacteria with ACC deaminase can promote plant growth and help to feed the world. - Microbiological Research 169: 30-39.

[18] Gomes, N. C., Fagbola, O., Costa, R., Rumjanek, N. G., Buchner, A., Mendona-Hagler, L. (2003): Dynamics of fungal communities in bulk and maize rhizosphere soil in the tropics. - Applied and Environmental Microbiology 69: 3758-3766.

[19] Guriguis, M. A., Kunc, F., Vancura, V. (1969): Presence and oxidation of amino acids in rhizosphere and nonrhizosphere soil. - Folia Microbiology 14: 1-12.

[20] He, W., Miao, G., Zhang, Y. (2006): Study on wheat quality zone in Shanxi province. Journal of Shanxi Normal University (Natural Science Edition) 20(2): 82-83. 
[21] Jia, Z. H., Sun, M., Yang, Z. P. (2004a): Influence of different fertilizers to crop rhizosphere microorganisms. - Acta Agronomica Sinica 30(5): 491-495 (in Chinese).

[22] Jia, Z. H., Yang, Z. P., Zhang, Y. Q. (2004b): Study on the quantity of three main molony of soil microbe in wheat farmland. - Journal of Triticeae Crops 24(3): 53-56 (in Chinese).

[23] Joergensen, R. G. (2000): Ergosterol and microbial biomass in the rhizosphere of grassland soils. - Soil Biology and Biochemistry 32: 647-652.

[24] Kasim, W. A., Osman, M. E., Omar, M. N., El-Daim, I. A. A., Bejai, S., Meijer, J. (2013): Control of drought stress in wheat using plant-growth-promoting bacteria. Journal of Plant Growth Regulation 32: 122-130.

[25] Kaya, Y., Akcura, M. (2014): Effects of genotype and environment on grain yield and quality traits in bread wheat (T. aestivum L.). - Food Science and Technology 34(2): 386393.

[26] Kourtev, P., Ehrenfeld, J., Häggblom, M. (2003): Experimental analysis of the effect of exotic and native plant species on the structure and function of soil microbial communities. - Soil Biology and Biochemistry 35: 895-905.

[27] Lakshmanan, V., Castaneda, R., Rudrappa, T., Bais, H. P. (2013): Root transcriptome analysis of Arabidopsis thaliana exposed to beneficial Bacillus subtilis FB17 rhizobacteria revealed genes for bacterial recruitment and plant defense independent of malate efflux. - Planta 238: 657-668.

[28] Li, F. D. (1993): Prosperous areas of current soil microbiology. - Acta Pedologica Sinica 30(3): 229-235 (in Chinese).

[29] Liu, T. T., Wang, B. Q., Yang, Z. P., Sun, M., Hao, J. M., Du, T. Q. (2015): Development Behavior and quality properties of nine winter wheat varieties from the Yellow-Huai River and Yangtse River middle-downstream winter wheat zone in Jinzhong. - Journal of Triticeae Crops 2: 182-191 (in Chinese).

[30] Lou, L. H. (1962): Roles of Soil Microbial on the Change of Soil Nutrient (1st ed.). Science Press, Beijing, pp. 283-287 (in Chinese).

[31] Lü, Y. H., Qin, S. Y. (2002): Soil Measure and Fertilization. - Chinese Agricultural Press, Beijing, pp. 48-84.

[32] Ma, J. J., Yang, Z. P., Xia, Q., Wang, B. Q., Sun, M., Gao, Z. Q. (2016): Study on yield and quality traits of color wheat varieties in Jinzhong wheat area. - Journal of Shanxi Agricultural Sciences 11: 1615-1618, 1668.

[33] Marschner, P., Crowley, D., Yang, C. H. (2004): Development of specific rhizosphere bacterial communities in relation to plant species, nutrition and soil type. - Plant and Soil 261: 199-208.

[34] Martin, J. K. (1977): Factors influencing the loss of organic carbon from wheat roots. Soil Biology and Biochemistry 9: 1-7.

[35] Miao, G. Y., Jia, Z. H., Yang, Z. P., Zhang, Y. Q. (2004): Quantity difference of rhizosphere microbe of different crops. - Journal of Shanxi Agricultural University 24(2): 93-96 (in Chinese).

[36] Muyzer, G., De Waal, E. C., Uitterlinden, A. G. (1993): Uitterlinden. Profiling of complex microbial populations by denaturing gradient gel electrophoresis analysis of polymerase chain reaction-amplified genes coding for 16S rRNA. - Applied and Environmental Microbiology 59(3): 695-700.

[37] Neal, A. L., Ahmad, S., Gordon-weeks, R., Ton, J. (2012): Benzoxazinoids in root exudates of maize attract Pseudomonas putida to the rhizosphere. - PLos One 7: e35498.

[38] Nelson, A., Frick, B., Clapperton, J., Quideau, S., Spaner, D. (2008): Does wheat cultivar choice affect crop quality and soil microbial communities in cropping systems? - 16th IFOAM Organic World Congress, Modena, Italy, June 16-20, 2008.

[39] Niemi, R. M., Heiskanen, I., Wallenius, K., Lindström, K. (2001): Extraction and purification of DNA in rhizosphere soil samples for PCR-DGGE analysis of bacterial consortia. - Journal of Microbiological Methods 45: 155-165. 
[40] Nuttall, J. G., O’Leary, G. J., Panozzo, J. F., Walker, C. K., Barlow, K. M., Fitzgerald, G. J. (2017): Models of grain quality in wheat-A review. - Field Crops Research 202: 136145.

[41] Piromyou, P., Buranabanyat, B., Tantasawat, P., Tittabutr, P., Boonkerd, N., Teaumroong, N. (2011): Effect of plant growth promoting rhizobacteria (PGPR) inoculation on microbial community structure in rhizosphere of forage corn cultivated in Thailand. - European Journal of Soil Biology 47: 44-54.

[42] Sainia, V. K., Bhandarib, S. C., Tarafdar, J. C. (2004): Comparison of crop yield, soil microbial $\mathrm{C}, \mathrm{N}$ and $\mathrm{P}, \mathrm{N}$-fixation, nodulation and mycorrhizal infection in inoculated and non-inoculated sorghum and chickpea crops. - Field Crops Research 89: 39-47.

[43] Schlemper, T. R., Leite, M. F., Lucheta, A. R., Shimels, M., Bouwmeester, H. J., van Veen, J. A., Kuramae, E. E., Bouwmeester, J. A. van Veen, et al. (2017): Rhizobacterial community structure differences among sorghum cultivars in different growth stages and soils. - Federation of European Microbiology Ecology 93(8).

[44] Singh, B. K., Munro, S., Potts, J. M., Millard, P. (2007): Influence of grass species and soil type on rhizosphere microbial community structure in grassland soils. - Applied Soil Ecology 36: 147-155.

[45] Su, L., Yang, Z., Xia, Q. (2017): Grain yield and quality traits research of Canada durum wheat in Jinzhong region. - Journal of Shanxi Agricultural University (Natural Science Edition) 37(3): 158-163 (in Chinese).

[46] Takuya, M. (1990): Turnover of microbial biomass nitrogen in rhizosphere soil of upland crops. - Plant and Soil 116: 179-188.

[47] Teaumroong, N., Wanapu, C., Chankum, Y., Arjharn, W., Sang-Arthit, S., Teaimthaisong, K. (2010): Production and Application of Bioorganic Fertilizers for Organic Farming Systems in Thailand: A Case Study. - In: Insam H, Franke-Whittle I, Goberna, M. (eds.) Microbes at Work. Springer, Berlin, Heidelberg; pp. 293-312.

[48] Tian, Z. G., Gao, T., Yang, G. (2013): Situation and existing problems of wheat production in Shanxi province. - Sci-Tech information Development \& Economy 23(17): 139-141 (in Chinese).

[49] van Dam, N. M., Bouwmeester, H. J. (2016): Metabolomics in the rhizosphere: tapping into belowground chemical communication. - Trends in Plant Science 21(3): 256-265.

[50] van der Heijden, M. G. A., Bardgett, R. D., van Straalen, N. M. (2008): The unseen majority: soil microbes as drivers of plant diversity and productivity in terrestrial ecosystems. - Ecology Letters 11(3): 296-310.

[51] Vázquez, M. M., César, S., Azcón, R., Barea, J. M. (2000): Interactions between arbuscular mycorrhizal fungi and other microbial inoculants (Azospirillum, Pseudomonas, Trichoderma) and their effects on microbial population and enzyme activities in the rhizosphere of maize plants. - Applied Soil Ecology 15(3): 261-272.

[52] Wakelin, S. A., Macdonald, L. M., Rogers, S. L., Gregg, A. L., Bolger, T. P., Baldock, J. A. (2008): Habitat selective factors influencing the structural composition and functional capacity of microbial communities in agricultural soils. - Soil Biology and Biochemistry 40: 803-813.

[53] Welbaum, G. E., Sturz, A. V., Dong, Z., Nowak, J. (2004): Managing soil microorganisms to improve productivity of agro-ecosystems. - Critical Reviews in Plant Sciences 23: 175-193.

[54] Weston, L. A., Ryan, P. R., Watt, M. (2012): Mechanisms for cellular transport and release of allelochemicals from plant root into the rhizosphere. - Journal of Experimental Botany 63(9): 3445-3454.

[55] Xia, Q., Yang, Z. P., Xi, J. F., Li, N., Sun, M., Gao, Z. Q. (2014): A study on yields and qualities traits of six wheat varieties (from Huanghuai wheat region) late-sowed in Jinzhong region. - Acta Laser Biology Sinica 23(2): 170-177. 
[56] Xiong, M. B., He, J. P., Song, G. Y. (2002): Effect of root exudations on ecological distribution of rhizospheric microorganisms. - Chinese Journal of Soil Science 33(2): 145-148 (in Chinese).

[57] Xiyong, C., Haixia, X., Zhongdong, D. O. N. G., Feng, C. H. E. N., Kehui, Z. H. A. N., Dangqun, C. (2012): Genetic evolution and utilization of wheat germplasm resources in Huanghuai winter wheat region of China. - Pakistan Journal of Botany 44(1): 281-288.

[58] Xu, Y., Wang, G., Jin, J., Liu, J., Zhang, Q., Liu, X. (2009): Bacterial communities in soybean rhizosphere in response to soil type, soybean genotype, and their growth stage. Soil Biology and Biochemistry 41: 919-925.

[59] Yang, Z., Yang, W., Li, S., Hao, J., Su, Z., Sun, M. (2016): Variation of bacterial community diversity in rhizosphere soil of sole-cropped versus intercropped wheat field after harvest. - PLoS One 11(3): e0150618.

[60] Zhang, J., Subramanian, S., Stacey, G., Yu, O. (2009): Flavones and flavonols play distinct critical roles during nodulation of Medicago truncatula by Sinorhizobium meliloti. - The Plant Journal for Cell and Molecular Biology 57(1): 171-183.

[61] Zhu, J. P., Cheng, K. (2011): Effect of organic acids exuded from hydroponic plants roots on nitrogen cycling bacteria. - Chinese Journal of Environmental Engineering 5(9): 21392143 (in Chinese).

\section{ELECTRONIC APPENDICES}

Attachment 1: Sequences of bacteria

Attachment 2: Sequences of fungi

Attachment 3: Accession numbers 